\title{
In vitro gas production and degradation kinetics of elephant grass silage with dried tamarind residue
}

\author{
D.R. Menezes ${ }^{1}$, A.L. Barbosa ${ }^{1}$, R.T.S. Rodrigues ${ }^{3,6}$, F.N. Lista ${ }^{2}$, T.V.C. Nascimento ${ }^{4}$, S.A. Moraes ${ }^{5}$, \\ M.A.Á. Queiroz ${ }^{2}$ and K.C. Busato ${ }^{3}$ \\ Federal University of São Francisco Valley \\ ${ }^{1}$ Department of Veterinary, ${ }^{2}$ Department of Animal Science, Petrolina PE, 56306-410 Brazil \\ ${ }^{3}$ Federal University of Lavras, Department of Animal Science, Lavras MG, 37200-000 Brazil \\ ${ }^{4}$ Federal University of Bahia, Department of Animal Science, Salvador BA, 40170-110 Brazil \\ ${ }^{5}$ Semiarid Embrapa, Petrolina PE, 56302-970 Brazil
}

KEY WORDS: Tamarindus indica, elephant grass silage, in vitro gas production, effective degradability, lag time

Received: 28 April 2015

Revised: 12 June 2016

Accepted: 26 August 2016

${ }^{6}$ Corresponding author: e-mail: rafael.nutricao@hotmail.com

\begin{abstract}
This study was conducted to evaluate fermentation, degradation kinetics and gas production of elephant grass silages enriched with dried tamarind (Tamarindus indica) residue (DTR). The experimental design was $4 \times 7$ factorial, with 4 inclusion levels of DTR $(0,8,16$ or $24 \%$ on an as-fed basis), and 7 silo opening times (days 1, 3, 6, 12, 24, 48 and 60), and 3 replicates. The kinetics of degradation and gas production were evaluated in the samples of silages opened at day 60 by the semi-automatic in vitro gas production technique. Silages with the inclusion of DTR showed lower $\mathrm{pH}$ values $(P<0.05)$ until the day 6 . The $\mathrm{N}-\mathrm{NH}_{3}$ concentration did not differ $(P>0.05)$ between DTR levels and silo opening times. The inclusion of DTR in the ensiling of elephant grass increased silage dry matter (DM) content and caused a linear decrease ( $P<0.05)$ in all parameters evaluated for gas production. At each $8 \%$ increase in DTR inclusion, the maximum total volume of gas production, gas production rate from total carbohydrates and time of colonization decreased by $6.1 \mathrm{ml} \cdot \mathrm{g}^{-1}$ of DM, $0.006 \mathrm{ml} \cdot \mathrm{g}^{-1}$ of DM $\cdot \mathrm{h}^{-1}$, and $2.4 \mathrm{~h}$, respectively. However, the effective degradability increased linearly $(2.2 \%)$ at each $8 \%$ increase in DTR inclusion $(P<0.05)$. In conclusion, it was observed that the $24 \%$ inclusion of DTR to elephant grass silage provided a more rapid reduction in $\mathrm{pH}$, reduced the in vitro gas production and increased DM degradability.
\end{abstract}

\section{Introduction}

Livestock farming is one of the main economic activities in the Brazilian semiarid region. Due to the irregular rainfalls and the long periods of drought, the use of forage conservation strategies is required here. Silage production is one of such strategies helping to conserve forage and to enable ruminant production in semiarid regions (Baraza et al., 2009). However, ensiling involves some risks that may lead to the loss of nutrients from undesirable fermentations.

Tamarind (Tamarindus indica) is a fruit tree native to Tropical Africa, from where it was dispersed throughout the world. In Brazil, tamarind is mostly found in the semiarid region, where it was well adapted to climate and soil conditions. Its fruit is an elongated pod 5-15 cm long, composed of a thin 
brittle woody shell, with 3-8 seeds embedded in an acidic pulp (Sousa et al., 2010). The tamarind fruit is used mainly in the juice and jelly production, and during the producing process large quantities of byproducts, like bagasse, bark and seeds, that could be used as animal feed are generated. The production of tamarind juice generates up to $60 \%$ of residue (Pereira et al., 2009).

Bhatta et al. (2000) used the tamarind seed husk in diets for dairy cows and did not observe any negative effect on performance and digestibility of organic matter. Subsequently, Bhatta et al. (2001) showed that the in vitro gas production was lower in the diets with the addition of tamarind seed husk.

The elephant grass (Pennisetum purpureum) ensiling is usually not effective because of its high moisture and low non-fibre carbohydrates content. Thus, the use of fruit processing by-products as additives during elephant grass ensiling has increased (Ferreira et al., 2015; Guerra et al., 2016). These by-products are usually dehydrated and their usage increases the dry matter of elephant grass silage and provides greater amounts of non-fibre carbohydrates, which contribute to a more rapid drop in $\mathrm{pH}$ and, consequently, a better stability and quality of the silage (Rêgo et al., 2010). However, the dried tamarind residue (DTR) inclusion in the elephant grass silage has not been reported. Thus, our hypothesis was that the use of DTR as an additive would improve the fermentation, degradation kinetics and in vitro gas production of elephant grass silages.

The aim of this study was to evaluate the fermentation, degradation kinetics and in vitro gas production of elephant grass silages enriched with different DTR levels $(0,8,16$ or $24 \%$ on an as-fed basis).

\section{Material and methods}

The research was conducted in the Metabolic and Gas Production Laboratories of the Federal University of São Francisco Valley (UNIVASF), located in Petrolina, Pernambuco (Brazil). All animal procedures were approved by the bioethics committee of the UNIVASF.

\section{Experimental design and ensiling of elephant grass with DTR}

The experimental design was $4 \times 7$ factorial (4 DTR levels and 7 silo opening times) with 3 replicates, in total 84 silos. The DTR (composed of bagasse, bark and seeds of tamarind) was obtained from an agro-industry. The wet residue was collected directly from the processing platform and taken to the laboratory, where it was sun-dried and stored in raffia bags until ensiling time. The elephant grass was harvested from an experimental area of the UNIVASF and immediately ground in a forage harvester with sieves ( $5 \mathrm{~cm}$ in diameter).

The DTR was mixed with the elephant grass at $0,8,16$ or $24 \%$ on as-fed basis and put into $50 \mathrm{~cm}$ PVC mini-silos sealed with canvas and rubber. The mixture was pressed with a wooden piston at a density of approximately $600 \mathrm{~kg} \cdot \mathrm{m}^{-3}$. Samples of the ensiled material and ingredients were collected and stored for subsequent chemical analyses.

Silos were opened at day 1, 3, 6, 12, 24, 48 and 60 of fermentation. The entire content of each mini-silo was taken and homogenized in a plastic container, so representative samples could be collected. A part of each collected sample was used for the subsequent chemical analysis, while another portion was used to evaluate $\mathrm{pH}$ and ammonia nitrogen $\left(\mathrm{N}_{-} \mathrm{NH}_{3}\right)$ concentration as part of the total nitrogen.

\section{Chemical analysis}

Samples of ingredients and ensiled material at each fermentation period were pre-dried in a forced-ventilation oven at $55{ }^{\circ} \mathrm{C}$ for $72 \mathrm{~h}$, ground in a Wiley mill with $2 \mathrm{~mm}$ sieve (MA340, Marconi Ltd., Piracicaba, Brazil), and analysed according to AOAC International (2000) (Tables 1 and 2).

Table 1. Chemical composition of elephant grass and dried tamarind residue (DTR)

\begin{tabular}{llr}
\hline \multirow{2}{*}{ Indices } & Ingredients & \\
\cline { 2 - 3 } & elephant grass & DTR \\
\hline Dry matter (DM), \% & 22.6 & 83.4 \\
Components, \% DM & & \\
organic matter & 87.7 & 96.2 \\
ash & 12.3 & 3.8 \\
crude protein & 7.6 & 11.0 \\
ether extract & 2.3 & 1.1 \\
non-fibre carbohydrates & 1.6 & 40.1 \\
NDF & 76.2 & 44.0 \\
ADF $^{2}$ & 48.0 & 37.1 \\
lignin & 9.3 & 18.5 \\
\hline
\end{tabular}

${ }^{1} \mathrm{NDF}$ - neutral detergent fibre, ${ }^{2} \mathrm{ADF}$ - acid detergent fibre

\section{In vitro kinetics of degradation and gas production}

The ruminal fluid used as inoculant was obtained from an adult castrated Holstein bull cannulated in the rumen. The animal was fed an elephantgrass-based diet ad libitum and supplemented daily with $1 \mathrm{~kg}$ of concentrate composed of maize meal, 
Table 2. Proportion of ingredients and chemical composition of ensiled material at day 0 and 60 of fermentation

\begin{tabular}{|c|c|c|c|c|}
\hline \multirow{2}{*}{ Indices } & \multicolumn{4}{|c|}{$\begin{array}{l}\text { Dried tamarind residue (DTR) inclusion } \\
\text { level, } \% \text { on an as-fed basis }\end{array}$} \\
\hline & 0 & 8 & 16 & 24 \\
\hline \multicolumn{5}{|c|}{ The initial silage component, \% } \\
\hline elephant grass & 100 & 92 & 84 & 76 \\
\hline DTR & 0 & 8 & 16 & 24 \\
\hline \multicolumn{5}{|c|}{ Chemical composition of the silages at day 0} \\
\hline $\begin{array}{l}\text { dry matter (DM), \% } \\
\text { components, \% DM }\end{array}$ & 22.6 & 27.1 & 35.0 & 37.7 \\
\hline organic matter & 87.7 & 88.1 & 90.6 & 90.3 \\
\hline ash & 12.3 & 11.9 & 9.4 & 9.7 \\
\hline crude protein & 7.6 & 8.6 & 8.6 & 8.6 \\
\hline $\mathrm{NDF}^{1}$ & 76.2 & 72.1 & 66.0 & 66.2 \\
\hline $\mathrm{ADF}^{1}$ & 48.0 & 45.1 & 44.8 & 42.6 \\
\hline \multicolumn{5}{|c|}{ Chemical composition of the silages at day 60} \\
\hline $\mathrm{DM}, \%$ & 22.7 & 29.1 & 32.3 & 38.4 \\
\hline \multicolumn{5}{|l|}{ components, \% DM } \\
\hline organic matter & 86.7 & 87.6 & 89.9 & 90.3 \\
\hline ash & 13.3 & 12.4 & 10.1 & 9.7 \\
\hline crude protein & 7.0 & 6.5 & 7.9 & 8.5 \\
\hline $\mathrm{NDF}^{1}$ & 72.4 & 67.6 & 66.0 & 64.5 \\
\hline $\mathrm{ADF}^{1}$ & 48.2 & 45.8 & 44.8 & 43.3 \\
\hline
\end{tabular}

${ }^{1}$ see Table 1

soyabean meal and urea. The collected ruminal fluid was filtered through a nylon sieve, stored in thermal bottles previously heated to $39^{\circ} \mathrm{C}$ and then taken to the laboratory.

Kinetics of degradation and gas production were evaluated in the samples of silos opened after 60 days of fermentation by the semi-automatic in vitro gas production technique proposed by Theodorou et al. (1994) and modified by Maurício et al. (2003). Samples of $0.5 \mathrm{~g}$ were weighted in non-woven textile (TNT) bags, which were placed in $160 \mathrm{ml}$ glass bottles. Subsequently, a mixture composed of $45 \mathrm{ml}$ of anaerobic buffer solution (Theodorou et al., 1994) and $5 \mathrm{ml}$ of ruminal fluid was added to each bottle. Then, the bottles were sealed with silicone caps and placed into boxes, which were manually stirred and kept in heated room at $39^{\circ} \mathrm{C}$.

The pressure in the bottles was measured by a pressure indicator (DPI 705, Druck Ltd., General Electric's ${ }^{\circledR}$; Leicester, UK). Pressure readings (in Pa) were taken at a higher frequency during the initial period of fermentation and subsequently reduced after 2, 4, 6, 8, 9, 11, 12, 14, 17, 20, 24, 28, 34, 48, 72,96 and $120 \mathrm{~h}$.

Cumulative gas production was analysed by a two-compartment model (Schofield et al., 1994):

$$
V(t)=V f 1 / 1+\mathrm{e}^{(2-4 m l(L-T))}+V f 2 / 1+\mathrm{e}^{(2-4 m 2(L-T))}
$$

where: $V(t)$ - maximum total volume of gas production, $V f 1$ - maximum volume of gas for the fraction of fast-degradation (non-fibre carbohydrate - NFC), $V f 2$ - maximum volume of gas for the slow-degradation fraction (fibre carbohydrate - FC), $m 1$ - gas production rate for the fraction of fast-degradation, $m 2$ - gas production rate for the slow-degradation fraction, $L-$ time of colonization (lag phase) and $T$ - time of fermentation.

Degradability of dry matter was estimated by removing TNT bags after 2, 6, 12, 24, 48, 96 and $120 \mathrm{~h}$ of in vitro incubation. Then, the bags were immersed in water with ice to stop the microbial fermentation and subsequently washed in running water and weighed after $12 \mathrm{~h}$ in an oven at $105^{\circ} \mathrm{C}$.

The model of Ørskov and McDonald (1979) was used to determine the potential degradability:

$$
\mathrm{PD}=a+b\left(1-\mathrm{e}^{-c t}\right)
$$

where: PD - potential degradability, $a$ - watersoluble fraction, $b$ - potentially degradable waterinsoluble fraction, $c$ - degradation rate of fraction $b, t$-incubation time (h), and e - natural log of -ct.

The effective degradability (ED) was calculated by:

$$
\mathrm{ED}=a+(b \times c) /(c+k p)
$$

where: $k p$ - the passage rate, which was estimated by the gas production rate of the total carbohydrates $(\mathrm{Mt}=m 1+m 2$; Menezes et al., 2015).

\section{Statistical analysis}

Statistical analyses were performed using the Statistical Analysis System (SAS 9.1). After analysis of variance (ANOVA), the Tukey's test at $5 \%$ of probability was applied for the results of $\mathrm{N}^{-\mathrm{NH}_{3}}$ concentration, $\mathrm{pH}$, and dry matter content of silages to compare the means in each fermentation period. The parameters of the gas production and ruminal degradability models were estimated by non-linear regression (NLIN) procedures. The parameters of fermentation of the silos opened after 60 days were compared by orthogonal contrasts and polynomial regression with a significance level of $5 \%$ by GLM and REG procedures.

\section{Results}

\section{Dry matter, $\mathrm{pH}$ and $\mathrm{N}-\mathrm{NH}_{3}$}

The dry matter (DM) content of silages did not differ $(P>0.05)$ between silo opening times (Table 3$)$. However, the inclusion of DTR in the ensiling of elephant grass increased $(P<0.05) \mathrm{DM}$ values in all opening times. The $\mathrm{pH}$ in the experimental silos 
Table 3. Dry matter (DM) content, $\mathrm{pH}$ and ammonia nitrogen $\left(\mathrm{N}_{-}-\mathrm{NH}_{3}\right)$ concentration of elephant grass silages with inclusions of dried tamarind residue (DTR) on an as-fed basis

\begin{tabular}{|c|c|c|c|c|c|c|c|c|}
\hline \multirow{2}{*}{ DTR } & \multicolumn{7}{|c|}{ Opening times, days } & \multirow{2}{*}{ SEM } \\
\hline & 1 & 3 & 6 & 12 & 24 & 48 & 60 & \\
\hline \multicolumn{9}{|l|}{$\% \mathrm{DM}^{1}$} \\
\hline $0 \%$ & $22.87^{A}$ & $23.88^{A}$ & $22.55^{\mathrm{A}}$ & $23.46^{A}$ & $23.29^{A}$ & $22.93^{\mathrm{A}}$ & $22.67^{A}$ & 0.164 \\
\hline $8 \%$ & $27.42^{B}$ & $25.50^{A}$ & $26.97^{\mathrm{A}}$ & $27.82^{A B}$ & $27.78^{B}$ & $27.90^{\mathrm{B}}$ & $29.14^{\mathrm{B}}$ & 0.828 \\
\hline $16 \%$ & $31.41^{\mathrm{C}}$ & $32.97^{\mathrm{B}}$ & $33.94^{\mathrm{B}}$ & $32.29^{B}$ & $32.21^{\mathrm{C}}$ & $34.13^{C}$ & $32.34^{B}$ & 0.121 \\
\hline $24 \%$ & $38.63^{D}$ & $39.72^{\mathrm{C}}$ & $40.64^{C}$ & $39.46^{C}$ & $36.88^{\mathrm{D}}$ & $36.61^{\mathrm{D}}$ & $38.36^{c}$ & 0.492 \\
\hline \multicolumn{9}{|l|}{$\mathrm{pH}$} \\
\hline $0 \%$ & $4.51^{\mathrm{eC}}$ & $4.34^{\mathrm{dB}}$ & $4.22^{\mathrm{cB}}$ & $4.17^{\mathrm{b}}$ & $4.19^{b c}$ & $4.14^{b}$ & $3.54^{\mathrm{a}}$ & 0.345 \\
\hline $8 \%$ & $4.42^{\mathrm{dC}}$ & $4.28^{\mathrm{cA}}$ & $4.20^{\mathrm{bcAB}}$ & $4.16^{\mathrm{bc}}$ & $4.20^{\mathrm{bc}}$ & $4.14^{\mathrm{b}}$ & $3.51^{\mathrm{a}}$ & 0.245 \\
\hline $16 \%$ & $4.27^{\mathrm{CB}}$ & $4.22^{\mathrm{bcA}}$ & $4.10^{\mathrm{bAB}}$ & $4.15^{\mathrm{bc}}$ & $4.19^{b c}$ & $4.13^{\mathrm{bc}}$ & $3.53^{\mathrm{a}}$ & 0.334 \\
\hline $24 \%$ & $4.16^{\mathrm{CA}}$ & $4.19^{\mathrm{CA}}$ & $4.05^{\mathrm{bA}}$ & $4.03^{b}$ & $4.02^{b}$ & $4.02^{b}$ & $3.57^{\mathrm{a}}$ & 0.898 \\
\hline \multicolumn{9}{|c|}{$\mathrm{N}-\mathrm{NH}_{3}$ concentration in \% total nitrogen } \\
\hline $0 \%$ & 6.62 & - & 5.09 & - & 5.77 & - & 5.82 & 21.7 \\
\hline $8 \%$ & 6.79 & - & 5.60 & - & 6.32 & - & 5.29 & 19.5 \\
\hline $16 \%$ & 5.45 & - & 5.35 & - & 5.17 & - & 7.41 & 22.6 \\
\hline $24 \%$ & 6.47 & - & 6.31 & - & 6.07 & - & 7.88 & 16.9 \\
\hline
\end{tabular}

${ }^{1}$ regression equation of dry matter on DTR levels in silage (at day 60 ): $\hat{y}=25.41+0.64 \mathrm{x} ; R^{2}=0.96, P<0.001$; means with different superscripts are significantly different at $(P<0.05)$ in rows $\left.{ }^{\left({ }^{-a d}\right.}\right)$ and columns $\left.{ }^{(A-D}\right)$, separately

decreased $(P<0.05)$ throughout the opening times (Table 3). Moreover, silages with the inclusion of DTR showed lower $\mathrm{pH}$ values $(P<0.05)$ until the sixth day. The $\mathrm{N}-\mathrm{NH}_{3}$ concentration did not differ $(P>0.05)$ between DTR levels and silo opening times (Table 3 ).

\section{In vitro kinetics of gas production and degradability}

The inclusion of DTR to the silages caused a linear decrease $(P<0.05)$ in all evaluated parameters of gas production (Table 4 ). At each $8 \%$ increase in DTR inclusion, the values of potential gas production from non-fibre (Vf1), fibre $(V f 2)$ and total $(V t)$ carbohydrates decreased by $4.0,2.1$, and $6.1 \mathrm{ml} \cdot \mathrm{g}^{-1}$ of DM, respectively, and the values of gas produc- tion rate from non-fibre $(\mathrm{m} I)$, fibre $(\mathrm{m} 2)$ and total $(M t)$ carbohydrates decreased by $0.005,0.0003$ and $0.006 \mathrm{ml} \cdot \mathrm{g}^{-1}$ of $\mathrm{DM} \cdot \mathrm{h}^{-1}$, respectively. In addition, the lag phase $(L)$ decreased by $2.4 \mathrm{~h}$ at each DTR inclusion increase of $8 \%$.

There was a greater difference between treatments on the cumulative gas production after $48 \mathrm{~h}$ of incubation (Figure 1-A,B,C). Furthermore, there was a greater reduction in gas production from the fermentation of non-fibre carbohydrates than from fibrous carbohydrates with DTR inclusion.

There was no difference $(P>0.05)$ for the degradability coefficients for water-soluble $(a)$ and potentially degradable water-insoluble fraction (b) (Table 5). The coefficient of degradation rate of fraction $b(c)$ increased linearly $(P<0.05)$ by

Table 4. In vitro gas production parameters of elephant grass silages at day 60 of fermentation with different dried tamarind residue (DTR) inclusion levels

\begin{tabular}{|c|c|c|c|c|c|c|c|}
\hline \multirow{2}{*}{ Parameter } & \multicolumn{4}{|c|}{ DTR, $\%$ on an as-fed basis } & \multirow{2}{*}{ SEM } & \multirow{2}{*}{$R^{2}$} & \multirow{2}{*}{$\begin{array}{l}\text { Regression } \\
\text { equations }\end{array}$} \\
\hline & 0 & 8 & 16 & 24 & & & \\
\hline \multicolumn{8}{|c|}{$\mathrm{ml} \cdot \mathrm{g}^{-1}$ dry matter (DM) } \\
\hline$V f_{1}$ & 84.62 & 80.00 & 73.94 & 73.20 & 1.043 & 0.83 & $\hat{y}=83.99-0.50 x$ \\
\hline$V f_{2}$ & 72.53 & 73.00 & 71.62 & 65.43 & 1.153 & 0.30 & $\hat{y}=74.24-0.26 x$ \\
\hline$V t$ & 157.15 & 153.00 & 145.56 & 138.63 & 1.907 & 0.81 & $\hat{y}=158.24-0.76 x$ \\
\hline \multicolumn{8}{|c|}{$\mathrm{ml} \cdot \mathrm{g}^{-1} \mathrm{DM} \cdot \mathrm{h}^{-1}$} \\
\hline$m_{1}$ & 0.0488 & 0.0401 & 0.0358 & 0.0336 & 0.001 & 0.83 & $\hat{y}=0.047-0.0006 x$ \\
\hline$m_{2}$ & 0.0113 & 0.0100 & 0.0099 & 0.0101 & 0.000 & 0.50 & $\hat{y}=0.011-0.00004 x$ \\
\hline$M t$ & 0.0601 & 0.0501 & 0.0457 & 0.0437 & 0.002 & 0.92 & $\hat{y}=0.058-0.0007 x$ \\
\hline$L, h$ & 20.17 & 16.30 & 15.45 & 12.58 & 0.291 & 0.91 & $\hat{y}=19.66-0.30 x$ \\
\hline
\end{tabular}

$V f 1$ - potential gas production from non-fibre carbohydrates; $V f 2$ - potential gas production from fibre carbohydrates; $V t$ - potential gas production from total carbohydrates; $m 1$ - gas production rate from non-fibre carbohydrates; $m 2$ - gas production rate from fibre carbohydrates; $M t$ - gas production rate from total carbohydrates; $L$ - lag phase; $R^{2}$-determination coefficient; SEM - standard error of means 

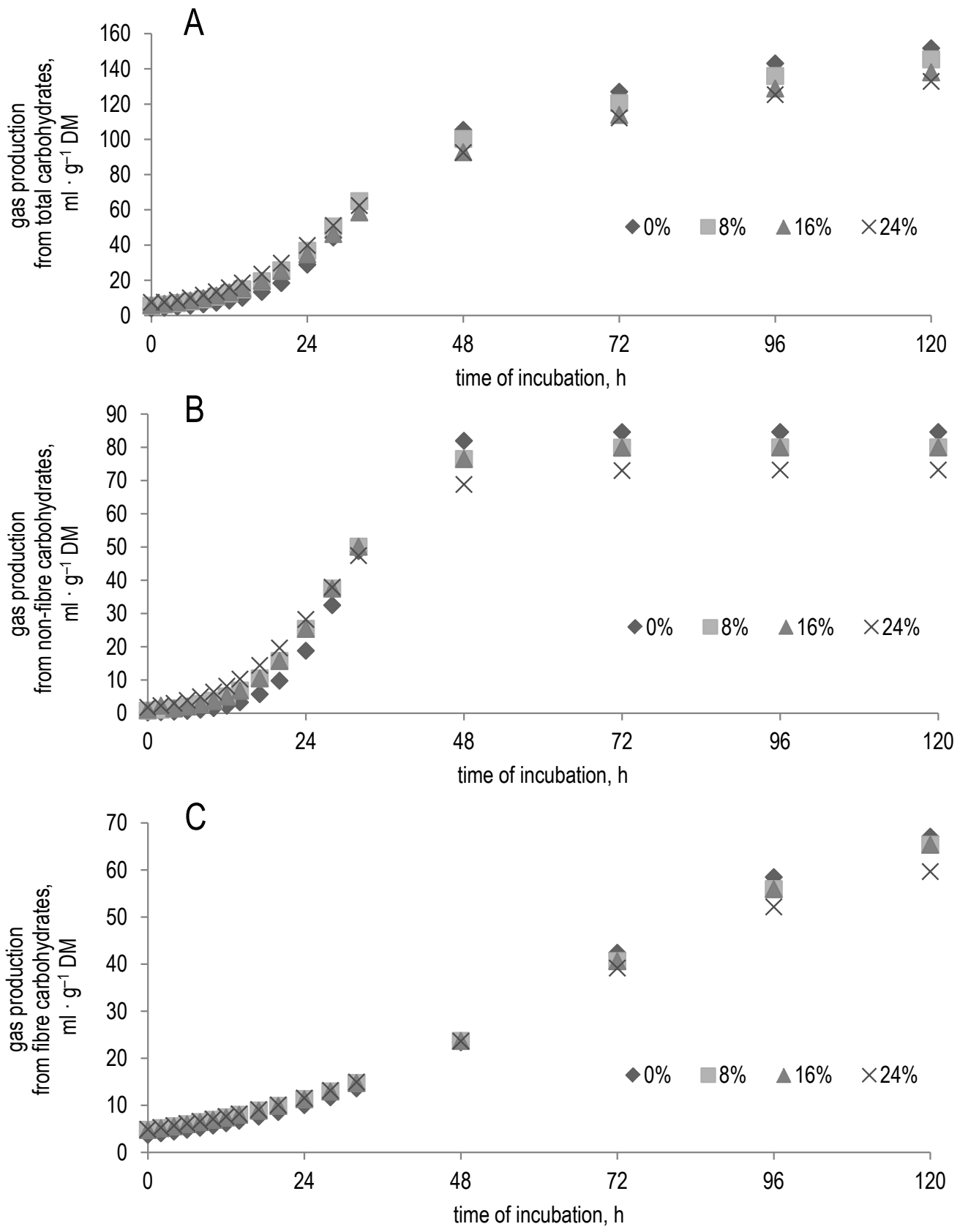

Figure 1. In vitro gas production from total carbohydrates (A), non-fibre carbohydrates (B), fibre carbohydrates $(\mathrm{C})$ of elephant grass silages with different dried tamarind residue (DTR) inclusion levels $(0,8,16$ and $24 \%$ on an as-fed basis)

Table 5. In vitro degradability coefficients of the dry matter (DM) of elephant grass silages at day 60 of fermentation with different dried tamarind residue (DTR) inclusion levels

\begin{tabular}{|c|c|c|c|c|c|c|c|}
\hline \multirow{2}{*}{ Coefficients } & \multicolumn{4}{|c|}{ DTR, \% on an as-fed basis } & \multirow{2}{*}{ SEM } & \multirow{2}{*}{$R^{2}$} & \multirow{2}{*}{ Regression equations } \\
\hline & 0 & 8 & 16 & 24 & & & \\
\hline$a, \% \mathrm{DM}$ & 20.3 & 22.4 & 20.5 & 20.9 & 0.70 & - & $\hat{y}=21.03$ \\
\hline$b, \% \mathrm{DM}$ & 61.7 & 58.9 & 58.7 & 59.5 & 1.80 & - & $\hat{y}=59.70$ \\
\hline$c, \% D M \cdot h^{-1}$ & 0.015 & 0.018 & 0.020 & 0.018 & 0.000 & 0.32 & $\hat{y}=0.016+0.00014 x$ \\
\hline$k p, \% \cdot h^{-1}$ & 0.060 & 0.050 & 0.046 & 0.044 & 0.002 & 0.92 & $\hat{y}=0.058-0.0007 x$ \\
\hline $\mathrm{PD}, \% \mathrm{DM}$ & 82.0 & 81.3 & 79.2 & 80.4 & 2.152 & - & $\hat{y}=80.73$ \\
\hline $\mathrm{ED}, \% \mathrm{DM}$ & 32.6 & 38.0 & 38.3 & 38.2 & 0.963 & 0.56 & $\hat{y}=33.55+0.27 x$ \\
\hline
\end{tabular}

$a$ - soluble fraction; $b$ - insoluble fraction, but degradable; $c$ - degradation rate of fraction $b$; PD - potential degradability; ED - effective degradability; $k p$ - passage rate estimated by gas production rate from total carbohydrate (Mt, see Table 4$) ; R^{2}-$ determination coefficient; SEM - standard error of means 
$0.0011 \%$ of DM $\cdot \mathrm{h}^{-1}$ at each $8 \%$ increase in DTR inclusion (Table 5). The potential degradability (PD) of DM was not affected $(P>0.05)$ by the inclusion of DTR $(P>0.05)$, while the effective degradability (ED) increased linearly $(P<0.05$; Table 5$)$. For each $8 \%$ increase in DTR inclusion, the ED increased by $2.2 \%$. There was an increase of approximately $20 \%$ in the ED when the treatment without DTR was compared with $24 \%$ of DTR inclusion.

\section{Discussion}

DM, $\mathbf{p H}$ and $\mathbf{N}-\mathbf{N H}_{3}$. The higher DM content in the silages with the DTR increased inclusion may be explained by the greater DM content of DTR when compared to the elephant grass. DM content could affect the amount of substrate required for the $\mathrm{pH}$ reduction necessary to stop the activity of lactic acid bacteria. Generally, the higher DM content of the ensiled material, the lower amount of substrate fermented (Muck, 1988).

The $\mathrm{pH}$ and $\mathrm{N}-\mathrm{NH}_{3}$ are among the main indices to evaluate the quality of silage fermentation (Charmley, 2001). In silages opened after 60 days there was measured lower $\mathrm{pH}$ than the recommended maximum (4.2), thus classifying the silage of all treatments as having good quality (Woolford, 1984). Interestingly, silages with $24 \%$ inclusion of DTR reached a $\mathrm{pH}$ below 4.2 at the first day of fermentation. On the other hand, silages without DTR inclusion reached a $\mathrm{pH}$ lower than 4.2 at day 12 of fermentation. The higher non-fibre carbohydrate content could be related to the more rapid decrease in $\mathrm{pH}$ in silages with DTR inclusion.

Additionally, the values of $\mathrm{N}-\mathrm{NH}_{3}$ found in the elephant grass silages in all opening days and DTR inclusion levels were lower than the maximum $12 \%$ mentioned by McDonald et al. (1991) when classifying good-quality silage, without the occurrence of undesirable proteolysis.

In vitro kinetics of gas production and degradation. The lower values of potential gas production from non-fibre $(V f 1)$, fibre $(V f 2)$ and total $(V t)$ carbohydrates, and gas production rate from nonfibre $(m l)$, fibre $(m 2)$ and total $(M t)$ carbohydrates as the DTR was included in the silages, could be related to the higher lignin content in DTR in comparison to the elephant grass, which might have limited the access of ruminal bacteria to the rapidly fermentable cell contents (Van Soest, 1994). This would also be associated with greater reduction in gas production from the fermentation of non-fibre carbohydrates than fibrous carbohydrates. Likewise,
Romero-Huelva et al. (2013) observed reduction in the amount of gas production when residues of tomato and cucumber were used in the production of blocks offered in goats' diet (as a commercial concentrate replacement).

Although the evaluation of tannin content has not been performed in this study, it has been reported that tamarind seed husk has a high (39\%) polymeric tannin content (Sinchaiyakit et al., 2011), which could have caused lower gas production in diets with tamarind seed (Bhatta et al., 2001). That is why high tannin levels may inhibit the availability of substrates and ruminal bacteria activity (Patra and Saxena, 2010). Thus, we could suggest that the lower gas production as DTR was included in the silages would be partially related to the high tannin content in tamarind seed. However, to confirm this hypothesis further studies are needed.

The decrease in lag phase $(L)$ as the DTR content was increased in the silages might be explained in part by a greater amount of non-fibre carbohydrates in DTR, which would be advantageous for the feed particles colonization, thereby reducing the $L$ marking the beginning of fermentation. The reduction of $L$ is favoured by the presence of readily fermentable substrates, and physical and chemical characteristics of the cell wall to facilitate microbial colonization (Tomich et al., 2003). Hernández et al. (2012) also observed a linear decrease in $L$ as they increased the levels of dried citrus pulp $(0,10,20$ and $30 \%$ ) in a total mixed ration for goats.

In addition, the lower $L$ as the DTR was included in the elephant grass silages would be partially related to the fact that differences in the cumulative gas production between treatments were more evident after $48 \mathrm{~h}$ of incubation, so the lower $L$ with the greater availability of non-fibrous carbohydrates would compensate the effect of higher lignin content in DTR on the initial fermentation.

Despite the reduced gas production as the DTR was included in the silages, the DM effective degradability (ED) increased. This result could be related to the increase in degradation rate of insoluble fraction $(c)$ and decrease in passage rate estimated by gas production from total carbohydrates $(k p)$ as the DTR was included in the silage. Bhatta et al. (2001) also observed an increase in the dry matter disappearance rate as the tamarind seed husk was included in diets incubated in vitro. The higher $c$ with DTR inclusion would be related to its greater content of nonfibre carbohydrates, which have higher fermentation rate than fibre carbohydrates. Piquer et al. (2009) by an exponential model reported a high positive corre- 
lation between the fractional degradation rate and the soluble sugar content in citrus fruit wastes.

Interestingly, there was a decrease in the gas production rate and an increase in the DM disappearance rate as the DTR was added to the silage. This result would suggest higher ruminal microbial efficiency with the addition of DTR, which would be related to the higher content of non-fibre carbohydrates in DTR, and the increase in crude protein and decrease in neutral detergent fibre content as the DTR was included in the elephant grass silages. Bhatta et al. (2001) reported an increase in the efficiency of microbial protein synthesis as the tamarind seed husk was included in diets incubated in vitro.

\section{Conclusions}

The inclusion of up to $24 \%$ of dried tamarind residue (DTR) in elephant grass silage provides more rapid reduction in $\mathrm{pH}$, reduces the in vitro gas production, and increases the effective degradability. The results indicate that such inclusion of DTR in the elephant grass silage is not harmful to in vitro ruminal degradation. In vivo studies to evaluate the effect of DTR inclusion in elephant grass silage on intake, digestibility and performance are recommended.

\section{References}

AOAC International, 2000. Official Methods of Analysis of AOAC International. 17 ${ }^{\text {th }}$ Edition. Gaithersburg, MD (USA)

Baraza E., Ángeles S., García A., Valiente-Banuet A., 2009. Adoption of silage as a methodology to improve domestic goat productivity for marginal farmers of the Tehuacán Valley in México. Livest. Res. Rural Dev. 21, www.Irrd.org/lrrd21/9/ajay21149.htm

Bhatta R., Krishnamoorthy U., Mohammed F., 2000. Effect of feeding tamarind (Tamarindus indica) seed husk as a source of tannin on dry matter intake, digestibility of nutrients and production performance of crossbred dairy cows in mid-lactation. Anim. Feed Sci. Tech. 83, 67-74

Bhatta R., Krishnamoorthy U., Mohammed F., 2001. Effect of tamarind (Tamarindus indica) seed husk tannins on in vitro rumen fermentation. Anim. Feed Sci. Tech. 90, 143-152

Charmley E., 2001. Towards improved silage quality - A review. Can. J. Anim. Sci. 81, 157-168

Ferreira A.C.H., Rodriguez N.M., Neiva J.N.M., Pimentel P.G., Gomes S.P., Campos W.E., Lopes F.C.F., 2015. Nutritional evaluation of elephant-grass silages with different levels of by-products from the cashew juice industry. Rev. Bras. Zootecn. 44, 434-442

Guerra D.G.F., Maia I.S.A.S., Braga A.P., Assis L.C.S.L.C., Lucena J.A., Bidler D.C., Santos Neto C.F., Medeiros e Silva Y.F., Pereira M.I.B., Pinto M.M.F., 2016. Chemical composition of elephant grass silages supplemented with different levels of dehydrated cashew bagasse. Semin. Ciênc. Agrár. 37, 997-1006

Hernández J., Rojo R., Salem A.Z.M., Mirzaei F., Gonzalez A., Vázquez J.F., Montañez O.D., Lucero F.A., 2012. Influence of different levels of dried citrus pulp on in vitro ruminal fermentation kinetics of total mixed ration in goat rumen inocula. J. Anim. Feed Sci. 21, 458-467
Maurício R.M., Pereira L.G.R., Gonçalves L.C., Rodriguez N.M., 2003. Relationship between volume and pressure for installation of the semi-automated in vitro gas production technique for tropical forage evaluation (in Portuguese). Arq. Bras. Med. Vet. Zoo. 55, 216-219

McDonald P., Henderson A.R., Heron S.J.E. (Editors), 1991. Biochemistry of Silage. $2^{\text {nd }}$ Edition. Chalcombe Publications. Marlow (UK)

Menezes D.R., Costa R.G., Araújo G.G.L., Pereira L.G.R., Nunes A. C.B., Henrique L.T., Rodrigues R.T.S., 2015. Ruminal kinetics of diets containing detoxicated castor bean meal (in Portuguese). Arq. Bras. Med. Vet. Zoo. 67, 636-641

Muck R.E., 1988. Factors influencing silage quality and their implications for management. J. Dairy Sci. 71, 2992-3002

Ørskov E.R., McDonald I., 1979. The estimation of protein degradability in the rumen from incubation measurements weighted according to rate of passage. J. Agr. Sci. 92, 499-503

Patra A.K., Saxena J., 2010. A new perspective on the use of plant secondary metabolites to inhibit methanogenesis in the rumen. Phytochemistry 71, 1198-1222

Pereira L.G.R., Azevedo J.A.G., Pina D.S., Brandão L.G.N., Araujo G.G.L., Voltolini T.V. (Editors), 2009. Aproveitamento dos Coprodutos da Agroindústria Processadora de Suco e Polpa de Frutas Para Alimentação de Ruminantes (in Portuguese). Embrapa Semi-Árido. Petrolina (Brazil)

Piquer O., Casado C., Biglia S., Fernández C., Blas E., Pascual J.J., 2009. In vitro gas production kinetics of whole citrus fruits. J. Anim. Feed Sci. 18, 743-757

Rêgo M.M.T., Neiva J.N.M., Rêgo A.C., Cândido M.J.D., Carneiro M.S.S., Lôbo R.N.B., 2010. Chemical and bromatological characteristics of elephant grass silages containing a mango by-product. Rev. Bras. Zootecn. 39, 81-87

Romero-Huelva M., Martín-García A.I., Nogales R., Molina-Alcaide E., 2013. The effects of feed blocks containing tomato and cucumber by-products on in vitro ruminal fermentation, microbiota, and methane production. J. Anim. Feed Sci. 22, 229-237

Schofield P., Pitt R.E., Pell A.N., 1994. Kinetics of fibre digestion from in vitro gas production. J. Anim. Sci. 72, 2980-2991

Sinchaiyakit P., Ezure Y., Sriprang S., Pongbangpho S., Povichit N., Suttajit M., 2011. Tannins of tamarind seed husk: preparation, structural characterization, and antioxidant activities. Nat. Prod. Commun. 6, 829-834

Sousa D.M.M., Bruno R.L.A., Dornelas C.S.M., Alves E.U., Andrade A.P., Nascimento L.C., 2010. Tamarind fruit and seed morphological characterization and post-seminal development Leguminosae: caesalpinioideae (in Portuguese). Rev. Árvore 34, 1009-1015

Theodorou M.K., Willians B.A., Dhanoa M.S., McAllan A.B., France J., 1994. A simple gas production method using a pressure transducer to determine the fermentation kinetics of ruminant feeds. Anim. Feed Sci. Tech. 48, 185-197

Tomich T.R., Gonçalves L.C., Maurício R.M., Pereira L.G.R., Rodrigues J.A.S., 2003. Bromatological composition and rumen fermentation kinetics of hybrids from crosses of sorghum and sudangrass (in Portuguese). Arq. Bras. Med. Vet. Zoo. 55, 747-755

Van Soest P.J. (Editor), 1994. Nutritional Ecology of the Ruminant. Cornell University Press. Ithaca, NY (USA)

Woolford M.K. (Editor), 1984. The Silage Fermentation. Microbiology Series, Vol. 14. Marcel Dekker, New York, NY (USA) 